\title{
Modulation of Amphetamine-Induced Dopamine Release by Group II Metabotropic Glutamate Receptor Agonist LY354740 in Non-Human Primates Studied with Positron Emission Tomography
}

\author{
Bart NM van Berckel*,', Lawrence S Kegeles',2, Rikki Waterhouse ${ }^{1,2}$, Ningning Guo', Dah-Ren Hwang ${ }^{1,2}$, \\ Yiyun Huang ${ }^{1,2}$, Rajesh Narendran', Ronald Van Heertum ${ }^{2}$ and Marc Laruelle ${ }^{1,2}$ \\ 'Department of Psychiatry, Columbia University, New York, NY, USA; ${ }^{2}$ Department of Radiology, Columbia University, New York, NY, USA
}

\begin{abstract}
Pharmacological evidence suggests that schizophrenia is associated with increased stimulation of dopamine (DA) $D_{2}$ receptors. Recently, several groups have demonstrated that amphetamine-induced DA release is increased in schizophrenia, providing direct evidence for dysregulation of DA systems in this condition. In healthy volunteers, pretreatment with the noncompetitive N-methyl-D-aspartate (NMDA) antagonist ketamine increases amphetamine-induced DA release to levels similar to those observed in patients with schizophrenia. Therefore, the dysregulation of DA function observed in schizophrenia might be secondary to NMDA hypofunction. In this study, the regulation of this response by glutamate (GLU) transmission was further characterized by using a metabotropic glutamate ( $\mathrm{mGlu}$ ) receptor group II agonist to inhibit GLU transmission. The amphetamine- $(0.5 \mathrm{mg} / \mathrm{kg}$ intravenously (i.v.)) induced decrease in $\left[{ }^{\prime \prime} \mathrm{C}\right.$ raclopride equilibrium-specific binding $\left(\mathrm{V}_{3}{ }^{\prime \prime}\right)$ was measured under control conditions and following pretreatment with the $\mathrm{mGlu} 2 / 3$ receptor agonist LY354740 (20 mg/kg i.v.) in four baboons. Amphetamine reduced [ ' ${ }^{\prime} \mathrm{C}$ ]raclopride $V_{3}{ }^{\prime \prime}$ by $28 \pm 7 \%$ under control conditions. Following LY354740 pretreatment, amphetamine-induced reduction in [ "C]raclopride $V_{3}$ " was significantly enhanced ( $35 \pm 7 \%, p=0.002)$. The enhancement of the amphetamine-induced reduction in [ ' C] raclopride $V_{3}$ " by LY 354740 was not a simple additive effect, as LY354740 alone did not reduce [ " C] raclopride $V_{3}{ }^{\prime \prime}$. In conclusion, the results of this study further document the involvement of GLU transmission in regulating the effect of amphetamine-induced DA release, and provide additional support to the hypothesis that the dysregulation of DA function revealed by the amphetamine challenge in schizophrenia might stem from a deficit in GLU transmission.

Neuropsychopharmacology (2006) 31, 967-977. doi:I 0.1038/sj.npp. I 300902; published online 21 September 2005
\end{abstract}

Keywords: glutamate; dopamine; schizophrenia; positron emission tomography; metabotropic glutamate receptors; non-human primates

\section{INTRODUCTION}

Schizophrenia is a chronic and severe mental illness characterized by disturbances of thought, perception, volition, and cognition. While the fundamental pathophysiology of schizophrenia remains unknown, several lines of evidences suggest that this illness is associated with increased dopamine (DA) transmission at $\mathrm{D}_{2}$ receptors (see, for reviews, Carlsson, 1978; Seeman, 1987; Weinberger,

\footnotetext{
*Correspondence: Dr BNM van Berckel. Current address: Department of Nuclear Medicine \& PET research, VU University Medical Center, De Boelelaan 1 117, Amsterdam 1007 MB, The Netherlands, Tel: ++312044442 |4, Fax: + + 31204444329, E-mail: B.Berckel@VUmc.nl Received 20 January 2005; revised 20 July 2005; accepted 5 August 2005

Online publication: 19 August 2005 at http://www.acnp.org/citations/ Npp081905050050/default.pdf
}

1987; Davis et al, 1991; Laruelle, 2003) and decreased glutamate (GLU) transmission at $N$-methyl-D-aspartate (NMDA) receptors (see, for reviews, Javitt and Zukin, 1991; Olney and Farber, 1995; Jentsch and Roth, 1999; Konradi and Heckers, 2003; van Berckel, 2003). With the advance of brain imaging techniques, direct evidence of dysregulation of DA transmission in schizophrenia has emerged. Three studies have reported an increase in amphetamine-induced DA release in patients with schizophrenia (Laruelle et al, 1996; Breier et al, 1997; AbiDargham et al, 1998). In these studies, increase in DA synaptic concentration was measured noninvasively by the decrease in $\mathrm{D}_{2}$ receptor availability to the binding of $\left[{ }^{11} \mathrm{C}\right]$ raclopride or $\left[{ }^{12} \mathrm{I}\right] \mathrm{IBZM}$.

Both putative neurochemical imbalances associated with schizophrenia (DA and GLU) might be related. Kegeles et al (2000) observed that enhanced amphetamine-induced DA 
release could be induced in healthy volunteers by pretreatment with the noncompetitive NMDA antagonist ketamine. Thus, alterations of DA function in schizophrenia might stem from a deficit in GLU-mediated negative feedback mechanisms modulating the activity of DA neurons. Yet, the net effect of acute ketamine administration on GLU transmission is complex. Ketamine blocks NMDA receptors, but also induces GLU release, resulting in the stimulation of other GLU receptors (Moghaddam et al, 1997; Moghaddam and Adams, 1998). Owing to this ambiguity, it was unclear if the enhancement of amphetamine effects induced by ketamine was ultimately due to a deficit or an excess of GLU transmission.

The aim of the present investigation was to clarify the glutamatergic mechanisms involved in the modulation of the amphetamine effect by ketamine previously observed in humans (Kegeles et al, 2000). Metabotropic GLU (mGlu) receptors are G-protein-coupled receptors that modulate brain excitability. To date, eight subtypes of mGlu receptors have been identified and classified into three subgroups (Nakanishi and Masu, 1994; Pin et al, 1999; Schoepp, 2002). Group II includes two subtypes, mGlu2 and mGlu3 receptors, which are located mainly perisynaptically. Activation of mGlu2/3 receptors reduces GLU release (East et al, 1995; Battaglia et al, 1997), whereas mGlu2/3 receptor antagonists amplify the elicited release of GLU (Di Iorio et al, 1996). Given their perisynaptic localization, mGlu2/3 receptors are activated mainly by GLU extrasynaptic spillover in conditions of enhanced GLU activity. Thus, mGlu2/3 receptors play a protective role against excessive GLU activity.

LY354740 is a highly selective agonist at mGlu2/3 receptors (Schoepp et al, 1997). Here, we investigated the effects of LY354740 on amphetamine-induced DA release using positron emission tomography (PET) and the $\left[{ }^{11} \mathrm{C}\right]$ raclopride displacement paradigm in baboons. The hypothesis was that pretreatment with LY354740 would blunt the glutamatergic response elicited in the negative feedback pathways by the outflow of DA induced by amphetamine. This mechanism would result in enhanced amphetamine effect on $\mathrm{D}_{2}$ receptor availability to $\left[{ }^{11} \mathrm{C}\right] \mathrm{ra}$ clopride.

\section{MATERIALS AND METHODS}

\section{General Design}

A total of 20 PET scans, performed on four baboons (Papio anubis; three male, one female, denoted A-D, between 4 and 6 years old, weighing $20.2 \pm 3.5 \mathrm{~kg}$ ), was performed in this study.

To study the modulation of amphetamine-induced DA release by LY354740, each of the four baboons underwent a set of four scans on two separate experimental days (total of 16 scans). The duration between $\left[{ }^{11} \mathrm{C}\right]$ raclopride injections was kept constant at $2 \mathrm{~h}$ (for the 10 scan pairs, this interval was $1.96 \pm 0.58 \mathrm{~h})$. In all scans, $\left[{ }^{11} \mathrm{C}\right]$ raclopride was administered as a single bolus injection. On each test day, a baseline $\left[{ }^{11} \mathrm{C}\right]$ raclopride scan was performed first. A second $\left[{ }^{11} \mathrm{C}\right]$ raclopride scan was performed after pretreatment with either amphetamine alone $(0.5 \mathrm{mg} / \mathrm{kg}$ intravenously (i.v.), administered in $30 \mathrm{~s}$ ) $5 \mathrm{~min}$ before tracer administration (amphetamine-alone day) or after pretreatment with LY354740 $(20 \mathrm{mg} / \mathrm{kg}$ i.v. in $3 \mathrm{~min}) 10 \mathrm{~min}$ before tracer administration followed by amphetamine $(0.5 \mathrm{mg} / \mathrm{kg}$ i.v. in $30 \mathrm{~s}) 5 \mathrm{~min}$ before tracer administration (LY354740 plus amphetamine day).

Two baboons (A and C) underwent the amphetaminealone test day first, and the LY354740 plus amphetamine day second. The other two baboons (B and $\mathrm{D}$ ) underwent the LY354740 plus amphetamine test day first, and the amphetamine-alone day second. Delays between experimental days were $23 \pm 11$ days (range, 14-35 days).

In addition, in one male baboon (D), the effect of LY354740 alone on $\left[{ }^{11} \mathrm{C}\right]$ raclopride binding was investigated. This baboon underwent two separate test days with a baseline $\left[{ }^{11} \mathrm{C}\right]$ raclopride scan and a $\left[{ }^{11} \mathrm{C}\right]$ raclopride scan after administration of $20 \mathrm{mg}$ LY354740 IV (total of four scans).

\section{Radiochemistry}

Astra Arcus Pharmaceutical Company (Sodertalje, Sweden) generously provided the precursor for the preparation of $\left.{ }^{11} \mathrm{C}\right]$ raclopride, $O$-desmethyl raclopride hydrobromide. $\left[{ }^{11} \mathrm{C}\right]$ Methyl triflate was produced by passing $\left[{ }^{11} \mathrm{C}\right]$ methyl iodide through a silver triflate furnace according to Jewett's procedure (Jewett, 1992). Briefly, $\left[{ }^{11} \mathrm{C}\right] \mathrm{CO}_{2}$ was bubbled into a tetrahydrofuran solution of lithium aluminum hydride. Concentrated hydrogen iodide was added, and $\left[{ }^{11} \mathrm{C}\right]$ methyl iodide was distilled through a stream of argon through a silver triflate furnace $\left(195^{\circ} \mathrm{C}\right)$ to yield $\left[{ }^{11} \mathrm{C}\right]$ methyl triflate, which was trapped in a solution of $O$-desmethyl raclopride hydrobromide and sodium hydroxide in dimethylsulfoxide. After a 5 -min reaction at $90^{\circ} \mathrm{C}$, the crude product was purified by high-pressure liquid chromatography (HPLC) (column: Phenomenex C18, $10 \mu \mathrm{m}, 25 \times 1 \mathrm{~cm}$; solvent: $30 \%$ acetonitrile and $70 \% \quad 0.1 \mathrm{~mol} / \mathrm{l}$ ammonium formate- $0.5 \%$ acetic acid; flow rate: $10 \mathrm{ml} / \mathrm{min}$ ). The product fraction was diluted with water and passed through a classic C18 Sep-Pak (Waters, Milford, MA, USA). The final product was recovered from the Sep-Pak using $1 \mathrm{ml}$ ethanol. The ethanol solution was mixed with saline and filtered through a $0.22-\mu \mathrm{m}$ filter and collected in a sterile vial.

\section{LY354740 Synthesis}

LY354740 was synthesized according to published methods (Monn et al, 1997). Proton NMR spectra were recorded using a Brucker $400 \mathrm{MHz}$ FT-NMR spectrometer (Department of Chemistry, Columbia University). Chemical shifts were recorded in p.p.m. from an internal tetramethylsilane standard in a $5 \%$ mixture of KOD in water-d2 and coupling constants are reported in Hertz $(\mathrm{Hz})$. Mass spectral analysis was performed with a ZAB-EQ mass spectrometer (Department of Chemistry, Columbia University). Melting point was determined with a Mel-Temp melting point apparatus and is uncorrected. Elemental analysis was performed by Atlantic Microlab Inc. (Norcross, Georgia) and experimental data were within $\pm 0.2 \%$ of the theoretical values. The final product presented as a granular white powder, and data obtained through the determination of melting point, proton NMR spectroscopy, mass spectral analysis, and elemental analysis matched the reported and theoretical 
values; $\mathrm{mp}=274-276^{\circ} \mathrm{C} ; 1 \mathrm{H}-\mathrm{NMR}\left(\mathrm{D}_{2} \mathrm{O}+\mathrm{KOD}\right): 1.12-1.35$ $(\mathrm{m}, 1 \mathrm{H}), 1.56(\mathrm{~m}, 1 \mathrm{H}), 1.82-2.17(\mathrm{~m}, 5 \mathrm{H}) ; \mathrm{MS} \mathrm{m} / z: 186$; Anal. $\left(\mathrm{C}_{8} \mathrm{H}_{11} \mathrm{NO}_{4} * \mathrm{H}_{2} \mathrm{O}\right): \mathrm{C}, \mathrm{H}$, and $\mathrm{N}$.

Sterile solutions of LY354740 suitable for i.v. injection were formulated according to Helton et al (1998). Briefly, sterile water $(29 \mathrm{ml})$ was added to LY354740 $(350 \mathrm{mg})$, and the resulting mixture was warmed gently to assist dissolution. After cooling, the $\mathrm{pH}$ was adjusted to approximately 7 with aqueous sodium hydroxide $(5 \mathrm{M})$. The resulting clear, colorless solution was filtered through a $0.2-\mu \mathrm{M}$ syringe filter (Acrodisc, Gelman Sciences) into a $30 \mathrm{ml}$ sterile vial. The $\mathrm{pH}$ of the solution was reconfirmed after sterile filtration.

\section{PET Protocol}

Baboon PET studies were performed according to protocols approved by the Columbia Presbyterian Medical Center Institutional Animal Care and Use Committee. The baboon was initially immobilized with ketamine $(10 \mathrm{mg} / \mathrm{kg}$ intramuscularly (i.m.)) and anesthetized with $1.8 \%$ isoflurane via an endotracheal tube. Isoflurane administration was kept stable during both scans. Owing to the short half-life of ketamine (Duvaldestin, 1981), anesthesia induction by ketamine does not affect $\left[{ }^{11} \mathrm{C}\right]$ raclopride binding (Hassoun et al, 2003). Vital signs were monitored every $10 \mathrm{~min}$ and the temperature was kept constant at $37^{\circ} \mathrm{C}$ with heated water blankets. An i.v. perfusion line was used for hydration and injection of radiotracers and nonradioactive drugs. A catheter was inserted in a femoral artery for arterial sampling. The head was positioned at the center of the field of view as defined by imbedded laser lines. The PET scans were performed with the ECAT EXACT HR+ (Siemens/CTI, Knoxville, TN, USA). The transaxial resolution in the three-dimensional (3-D) mode of the Siemens $\mathrm{HR}+\mathrm{PET}$ scanner varies between $4.1 \mathrm{~mm}$ FWHM in the center of the field of view and $7.8 \mathrm{~mm}, 20 \mathrm{~cm}$ outside the center (Brix et al, 1997). A bolus of $\left[{ }^{11} \mathrm{C}\right]$ raclopride was injected i.v. over $30 \mathrm{~s}$ by a computer-operated pump.

Emission data were collected in the 3-D mode for $61 \mathrm{~min}$ as 18 successive frames of increasing duration $(6 \times 10 \mathrm{~s}$, $2 \times 1 \mathrm{~min}, 4 \times 2 \mathrm{~min}, 2 \times 5 \mathrm{~min}, 4 \times 10 \mathrm{~min})$. PET emission data were attenuation-corrected using the transmission scan, and frames were reconstructed using a Shepp filter (cutoff 0.5 cycles/projection rays). Reconstructed image files were then processed by the MEDx image analysis software (Sensor Systems, Sterling, VA, USA). PET images were coregistered to a volumetric T1-weighted magnetic resonance image (MRI) of the baboon's brain using an automated registration algorithm (Woods et al, 1992). Striatal and cerebellar regions were drawn on the MRI and transferred to the registered PET frames. The striatal ROI encompassed the whole striatum volume. Timeactivity curves for each ROI were measured and decaycorrected. Right and left striatal regions were averaged.

\section{Input Function Measurement}

Following radiotracer injection, arterial samples were collected every $10 \mathrm{~s}$ for the first $2 \mathrm{~min}$ and every $20 \mathrm{~s}$ for the next 2 min with an automated sampling system, and manually thereafter at longer intervals (total of 30 samples per experiment). Following centrifugation (10 $\mathrm{min}$ at $1100 \mathrm{~g}$ ), plasma was collected and radioactivity was measured in a gamma counter (Wallac 1480). Six samples (2, 6, $12,20,40$, and $60 \mathrm{~min}$ ) were further processed by protein precipitation using acetonitrile followed by HPLC (Phenomenex C18 analytical column) to measure the fraction of plasma activity representing unmetabolized parent compound. The parent fractions were fitted to the sum of two exponentials. The input function was calculated as the product of total counts and fraction of parent compound. $\left[{ }^{11} \mathrm{C}\right]$ Raclopride clearance $\left(\mathrm{CL}, 1 \mathrm{~h}^{-1}\right)$ was calculated as the ratio of the area under the curve of the input function divided by the injected dose.

For the determination of the plasma free fraction $\left(f_{1}\right)$, triplicate $200 \mu \mathrm{l}$ aliquots of plasma collected before injection were mixed with radiotracer, pipetted into ultrafiltration units (Centrifree; Amicon, Danvers, MA), and centrifuged at room temperature $(20 \mathrm{~min}$ at 4000 r.p.m.). At the end of centrifugation, plasma and ultrafiltrate activities were counted, and $f_{1}$ was calculated as the ratio of ultrafiltrate to total activity concentrations (Gandelman et al, 1994).

\section{Amphetamine Plasma Measurement}

Amphetamine plasma levels were measured in one venous sample obtained at $50 \mathrm{~min}$ after amphetamine injection. Amphetamine was quantified as its $N$-heptafluorobutyryl derivative via gas chromatography/mass spectroscopy utilizing a capillary column with mass spectrometer with simultaneous ion monitoring in the negative chemical ionization mode and reactant gas methane/ammonia (95:5) (Reimer et al, 1993). Trideuterated amphetamine was used as the internal standard. Standard curves for both compounds are uniformly linear $(r>0.99)$ over the range tested $(0.1-500 \mathrm{ng} / \mathrm{ml})$ with negligible intercepts. Sensitivity is $<0.1 \mathrm{ng} / \mathrm{ml}$ for each when $1 \mathrm{ml}$ of plasma is extracted. Interassay RSD\% is $5.2 \%$ at $5 \mathrm{ng} / \mathrm{ml}$. For technical reasons, amphetamine plasma levels were obtained only in baboons $\mathrm{A}, \mathrm{B}$, and $\mathrm{C}$.

\section{Derivation of $\mathrm{D}_{2}$ Receptor Availability}

Derivation of $\left[{ }^{11} \mathrm{C}\right]$ raclopride regional distribution volumes was performed using kinetic analysis with a three-compartment model in the striatum and a two-compartment model in the cerebellum. The three-compartment configuration included the arterial plasma compartment $\left(C_{\mathrm{a}}\right)$, the intracerebral free and nonspecifically bound compartment (nondisplaceable compartment, $C_{2}$ ), and the specifically bound compartment $\left(C_{3}\right)$. Brain activity was corrected for the contribution of plasma activity assuming a $5 \%$ blood volume (Mintun et al, 1984).

The total regional distribution volume $\left(V_{\mathrm{T}}\right.$, milliliters of plasma per gram of tissue) was defined as the ratio of the tracer concentration in this region $\left(C_{\mathrm{T}}\right)$ to the metabolitecorrected plasma concentration at equilibrium:

$$
V_{\mathrm{T}}=\frac{C_{\mathrm{T}}}{C_{\mathrm{a}}}
$$

$V_{\mathrm{T}}$ is equal to the sum of the distribution volumes for the second (nondisplaceable, $V_{2}$ ) and third (specific, $V_{3}$ ) 
compartments. In the cerebellum, the density of $\mathrm{D}_{2}$ receptors is negligible, that is, $V_{3}=0$ and $V_{\mathrm{T}}=V_{2}$.

Kinetic rate constants were derived by nonlinear regression using a Levenberg-Marquardt least-squares minimization procedure (Levenberg, 1944) implemented in MATLAB (Math Works) as described previously (Laruelle et al, 1994). Given the unequal sampling over time (increasing frame acquisition time from beginning to end of the study), the least-squares minimization procedure was weighted by the square root of the frame acquisition time.

$V_{\mathrm{T}}$ was derived from the kinetic rate constants as:

$$
V_{\mathrm{T}}=\frac{K_{1}}{k_{2}}\left(1+\frac{k_{3}}{k_{4}}\right)
$$

where $K_{1}$ (in $\left.\mathrm{ml} / \mathrm{g} / \mathrm{min}\right)$ and $k_{2}\left(\mathrm{~min}^{-1}\right)$ are the unidirectional fractional rate constants for the transfer between $C_{\mathrm{a}}$ and $C_{2}$, and $k_{3}\left(\min ^{-1}\right)$ and $k_{4}\left(\min ^{-1}\right)$ are the unidirectional fractional rate constants for the transfer between $C_{2}$ and $C_{3}$. The terms $K_{1}$ and $k_{2}$ include the regional blood flow, and the term $V_{\mathrm{T}}$ is blood flow independent (the flow is present in both numerator and denominator and cancels out).

$\mathrm{D}_{2}$ receptor availability was estimated by the parameter $V_{3}{ }^{\prime \prime}$, derived from the distribution volumes according to (Laruelle et al, 1994):

$$
V_{3}^{\prime \prime}=\frac{V_{\mathrm{T} \mathrm{STR}}-V_{\mathrm{T} \mathrm{CER}}}{V_{\mathrm{T} \mathrm{CER}}}
$$

The relationship between $V_{3}^{\prime \prime}$ and the receptor parameters $B_{\max }$ (available density of receptors) and $K_{\mathrm{D}}^{\prime}$ (affinity of ${ }^{11} \mathrm{C}$ ]raclopride for $D_{2}$ receptors in the presence of the endogenous competitor DA) is given, under the assumption of a competitive interaction between $\left[{ }^{11} \mathrm{C}\right]$ raclopride and $\mathrm{DA}$, by the following equation (Laruelle et al, 1998)

$$
V_{3}^{\prime \prime}=\frac{B_{\max }}{V_{2} K_{\mathrm{D}}^{\prime}}=\frac{B_{\max }}{V_{2} K_{\mathrm{D}}\left(1+F_{\mathrm{DA}} / K_{\mathrm{I}}\right)}
$$

$K_{\mathrm{D}}$ is the affinity of $\left[{ }^{11} \mathrm{C}\right]$ raclopride for $\mathrm{D}_{2}$ receptors in the absence of DA, FDA is the free concentration of DA in the vicinity of receptors, and $K_{\mathrm{I}}$ is the affinity of DA for $\mathrm{D}_{2}$ receptors.

The amphetamine effect on $V_{3}{ }^{\prime \prime}$ was calculated by comparing $V_{3}^{\prime \prime}$ measured in the post-amphetamine experiment $\left(V_{3}^{\prime \prime}\right.$ AMPH $)$ relative to the baseline scan obtained on that day under baseline conditions ( $\left.V_{3}{ }^{\prime \prime}{ }_{\text {BASE }}\right)$

$$
\frac{\Delta V_{3}{ }^{\prime \prime}=100 \times V_{3}{ }^{\prime \prime} \text { AMPH }-V_{3}{ }^{\prime \prime} \text { BASE }}{V_{3}{ }^{\prime \prime} \text { BASE }}
$$

Equation (4) shows that an increased FDA, resulting from the challenge, translates into a corresponding decrease in $V_{3}{ }^{\prime \prime}$. Equation (4) also indicates that the attribution of changes in $V_{3}^{\prime \prime}$ solely to changes in FDA requires the assumption that all other parameters of this equation remain constant, including the nonspecific binding.

\section{Statistical Analysis}

Values were expressed as mean \pm SD. Unless otherwise specified, significant differences were assessed with repeated measures analysis of variance (ANOVA), with experimental condition as repeated factor. A two-tailed $p=0.05$ was selected as the significance level.

\section{RESULTS}

\section{Modulation of Amphetamine Effect on $\left[{ }^{11} \mathrm{C}\right]$ Raclopride} $V_{3}^{\prime \prime}$ by LY354740

Table 1 lists the injected doses and masses of $\left[{ }^{11} \mathrm{C}\right]$ raclopride in the 16 experiments. No between-condition differences were detected in the injected doses $(p=0.53)$ or masses $(p=0.27)$.

Table 2 lists the plasma free fraction, the plasma CL, and the nonspecific distribution volumes measured in the 16 experiments. No between-condition differences between baseline scans, amphetamine-alone scans, and amphetamine/LY354740 scans were detected in the plasma free fraction $(p=0.90)$, the plasma CL $(p=0.23)$, or the nonspecific distribution volumes $(p=0.76)$.

Table 3 lists striatal $\left[{ }^{11} \mathrm{C}\right.$ ]raclopride $V_{3}$ " values measured in each experiment. No significant differences were observed in baseline $V_{3}$ " between values measured on the amphetamine day and on the amphetamine plus LY354740 day $(p=0.86)$. Significant differences in baseline $V_{3}^{\prime \prime}$ were observed between baboons (single-factor ANOVA, $p=0.001)$. Comparing baseline $V_{3}^{\prime \prime}$ values across experi-

\begin{tabular}{|c|c|c|c|c|c|c|c|c|}
\hline \multirow{3}{*}{$\begin{array}{l}\text { Day } \\
\text { Condition } \\
\text { Baboon }\end{array}$} & \multicolumn{4}{|c|}{ Amphetamine-alone experimental day } & \multicolumn{4}{|c|}{ LY354740 plus amphetamine experimental day } \\
\hline & \multicolumn{2}{|c|}{ Baseline scan } & \multicolumn{2}{|c|}{ Post-amphetamine scan } & \multicolumn{2}{|c|}{ Baseline scan } & \multicolumn{2}{|c|}{ Post-LY354740 plus amphetamine scan } \\
\hline & ID (mCi) & IM ( $\mu \mathrm{g})$ & ID (mCi) & IM ( $\mu \mathrm{g})$ & ID (mCi) & IM ( $\mu g)$ & ID (mCi) & IM ( $\mu \mathrm{g})$ \\
\hline A & 6.58 & $|.6|$ & 6.93 & 1.43 & 6.47 & 1.74 & 4.85 & 1.18 \\
\hline B & 5.83 & 5.99 & 5.62 & 3.70 & 6.50 & 2.72 & 5.73 & 3.03 \\
\hline C & 6.35 & 2.95 & 5.21 & 1.49 & 4.98 & 2.89 & 5.06 & 1.82 \\
\hline$D$ & 5.72 & 0.87 & 6.50 & 1.28 & 5.59 & 0.77 & 6.29 & 0.92 \\
\hline Mean $\pm S D$ & $6.12 \pm 0.41$ & $2.86 \pm 2.26$ & $6.07 \pm 0.79$ & $1.98 \pm 1.15$ & $5.88 \pm 0.73$ & $2.03 \pm 0.98$ & $5.48 \pm 0.66$ & $1.74 \pm 0.94$ \\
\hline
\end{tabular}
mental days yielded a test/retest variability of $4 \pm 4 \%$, a within-subject coefficient of variation (\%CV) of $3.0 \%$, a

Table I [ ' 'C]Raclopride Injected Doses (ID) and Mass (IM) 
Table $2\left[{ }^{I}\right.$ ' $\left.C\right]$ Raclopride Parameters: Free Fraction in Plasma $\left(f_{1}\right)$, Clearance $(C L)$, and $V_{2}$

\begin{tabular}{|c|c|c|c|c|c|c|c|c|c|c|c|c|}
\hline \multirow{3}{*}{$\begin{array}{l}\text { Day } \\
\text { Condition } \\
\text { Baboon }\end{array}$} & \multicolumn{6}{|c|}{ Amphetamine alone experimental day } & \multicolumn{6}{|c|}{ LY354740 plus amphetamine experimental day } \\
\hline & \multicolumn{3}{|c|}{$\begin{array}{l}\text { Baseline } \\
\text { scan }\end{array}$} & \multicolumn{3}{|c|}{$\begin{array}{l}\text { Post-amphetamine } \\
\text { scan }\end{array}$} & \multicolumn{3}{|c|}{$\begin{array}{l}\text { Baseline } \\
\text { scan }\end{array}$} & \multicolumn{3}{|c|}{$\begin{array}{l}\text { Post-LY354740 plus } \\
\text { amphetamine scan }\end{array}$} \\
\hline & $f_{1}$ & $C L\left(I h^{-1}\right)$ & $V_{2}\left(\mathrm{mlg}^{-1}\right)$ & $f_{1}$ & $C L\left(I h^{-1}\right)$ & $V_{2}\left(\mathrm{mlg}^{-1}\right)$ & $f_{1}$ & $C L\left(I^{-1}\right)$ & $V_{2}\left(\mathrm{mlg}^{-1}\right)$ & $f_{1}$ & $C_{\mathrm{L}}\left(\mathrm{Ih}^{-1}\right)$ & $V_{2}\left(\mathrm{mlg}^{-1}\right)$ \\
\hline A & 0.08 & 28.9 & 0.67 & 0.08 & 29.5 & 0.70 & 0.09 & 27.4 & 0.81 & 0.09 & 31.0 & 0.72 \\
\hline C & 0.09 & 19.5 & 0.86 & 0.08 & 21.6 & 0.80 & 0.11 & 23.8 & 1.01 & 0.11 & 31.8 & 1.02 \\
\hline $\mathrm{D}$ & 0.12 & 23.9 & 0.72 & 0.12 & 30.5 & 0.76 & 0.11 & 23.2 & 0.88 & 0.12 & 27.3 & 0.96 \\
\hline Mean \pm SD & $10 \pm 2 \%$ & $25.6 \pm 4.9$ & $0.80 \pm 0.13$ & $10 \pm 2 \%$ & $31.1 \pm 8.7$ & $0.82 \pm 0.15$ & $10 \pm 1 \%$ & $25.4 \pm 2.2$ & $0.86 \pm 0.12$ & $10 \pm 2 \%$ & $29.8 \pm 2.0$ & $0.88 \pm 0.14$ \\
\hline
\end{tabular}

Table 3 Modulation of Amphetamine-Induced $\Delta V_{3}^{\prime \prime}$ by LY354740

\begin{tabular}{|c|c|c|c|c|c|c|}
\hline \multirow{2}{*}{$\begin{array}{l}\text { Day } \\
\text { Condition }\end{array}$} & \multicolumn{3}{|c|}{ Amphetamine alone experimental day } & \multicolumn{3}{|c|}{ LY354740 plus amphetamine experimental day } \\
\hline & $\begin{array}{l}\text { Baseline } \\
\text { scan }\end{array}$ & $\begin{array}{c}\text { Post-amphetamine } \\
\text { scan }\end{array}$ & $\begin{array}{c}\text { Amphetamine } \\
\text { effect }\end{array}$ & $\begin{array}{l}\text { Baseline } \\
\text { scan }\end{array}$ & $\begin{array}{l}\text { Post-LY354740 plus } \\
\text { amphetamine scan }\end{array}$ & $\begin{array}{l}\text { LY354740 plus } \\
\text { amphetamine effect }\end{array}$ \\
\hline Baboon & $V_{3}^{\prime \prime}$ & $V_{3}^{\prime \prime}$ & $\Delta V_{3}^{\prime \prime}(\%)$ & $V_{3}^{\prime \prime}$ & $\mathbf{V}_{\mathbf{3}}^{\prime \prime}$ & $\Delta V_{3}^{\prime \prime}(\%)$ \\
\hline A & 2.64 & 1.88 & -29 & 2.62 & 1.64 & -37 \\
\hline $\mathrm{D}$ & 2.24 & 1.68 & -25 & 2.41 & 1.64 & -32 \\
\hline Mean $\pm S D$ & $2.69 \pm 0.37$ & $1.92 \pm 0.20$ & $-28 \pm 7$ & $2.68 \pm 0.22$ & $1.74 \pm 0.19$ & $-35 \pm 7$ \\
\hline
\end{tabular}

between-subject $\% \mathrm{CV}$ of $12 \%$, and an intraclass correlation coefficient of 0.89 .

Amphetamine induced a significant effect on $V_{3}{ }^{\prime \prime}$, both on the amphetamine-alone day $(p=0.012)$ and on the amphetamine plus LY354740 day $(p=0.004$, Figure 1$)$. On the amphetamine-alone day, amphetamine induced a significant reduction of $28 \pm 7 \%$ in $\left[{ }^{11} \mathrm{C}\right]$ raclopride $V_{3}{ }^{\prime \prime}$. On the LY354740 plus amphetamine day, the LY354740/ amphetamine combination reduced $\left[{ }^{11} \mathrm{C}\right]$ raclopride $V_{3}{ }^{\prime \prime}$ by $35 \pm 7 \%$. The decrease in $\left[{ }^{11} \mathrm{C}\right]$ raclopride $V_{3}^{\prime \prime}$ was significantly larger on the LY354740/amphetamine day as compared with the amphetamine alone day $(p=0.002$, Figure 2).

The increased level of $\left[{ }^{11} \mathrm{C}\right]$ raclopride displacement was not due to differences in amphetamine plasma levels. On the amphetamine-alone days, plasma amphetamine levels were $122 \pm 20 \mathrm{ng} / \mathrm{ml}$. On the LY354740/amphetamine day, plasma amphetamine levels were $117 \pm 11 \mathrm{ng} / \mathrm{ml}(p=0.55)$.

No differences were observed in critical experimental/ biological parameters (systolic blood pressure, diastolic blood pressure, heart rate, respiratory rate, temperature, isoflurane concentration) between the amphetamine-alone and the LY354740/amphetamine experiments, neither before nor after the administration of the challenge drugs (Table 4). A nonsignificant difference in isoflurane levels occurred between baseline scans on the amphetamine-alone day and the LY354740 plus amphetamine day $(p=0.11$, repeated measures ANOVA). However, there was no correlation between the baseline anesthesia level differences and the $V_{3}{ }^{\prime \prime}$ percent reduction differences induced by the combined challenge $\left(R^{2}=0.08, p=0.72\right)$ nor between the baseline anesthesia differences and the baseline $V_{3}{ }^{\prime \prime}$ differences $\left(R^{2}=0.26, p=0.49\right)$.

\section{Effect of LY354740 Alone on $\left[{ }^{11} \mathrm{C}\right]$ raclopride $V_{3}{ }^{\prime \prime}$}

Table 5 lists $\left[{ }^{11} \mathrm{C}\right.$ ]raclopride $V_{3}{ }^{\prime \prime}$ values at baseline and after administration of $20 \mathrm{mg}$ LY354740 i.v. on two separate occasions in baboon D. LY354740 alone induced an increase of $V_{3}^{\prime \prime}$ binding of $13 \pm 2 \%$. While this effect did not reach significance, possibly due to the low number of observations $(p=0.14)$, this observation allowed rejection of the hypothesis that LY354740 alone induced a decrease in $\left[{ }^{11} \mathrm{C}\right]$ raclopride $V_{3}{ }^{\prime \prime}$.

\section{DISCUSSION}

In this study, acute administration of the group II metabotropic agonist LY354740 increased the effect of amphetamine on striatal $\left[{ }^{11} \mathrm{C}\right]$ raclopride $V_{3}{ }^{\prime \prime}$. On the amphetamine-alone day, amphetamine $(0.5 \mathrm{mg} / \mathrm{kg})$ reduced $\left[{ }^{11} \mathrm{C}\right.$ ]raclopride $V_{3}{ }^{\prime \prime}$ by $28 \pm 7 \%$, a response consistent with previous observations (Laruelle et al, 1997). After pretreat- 

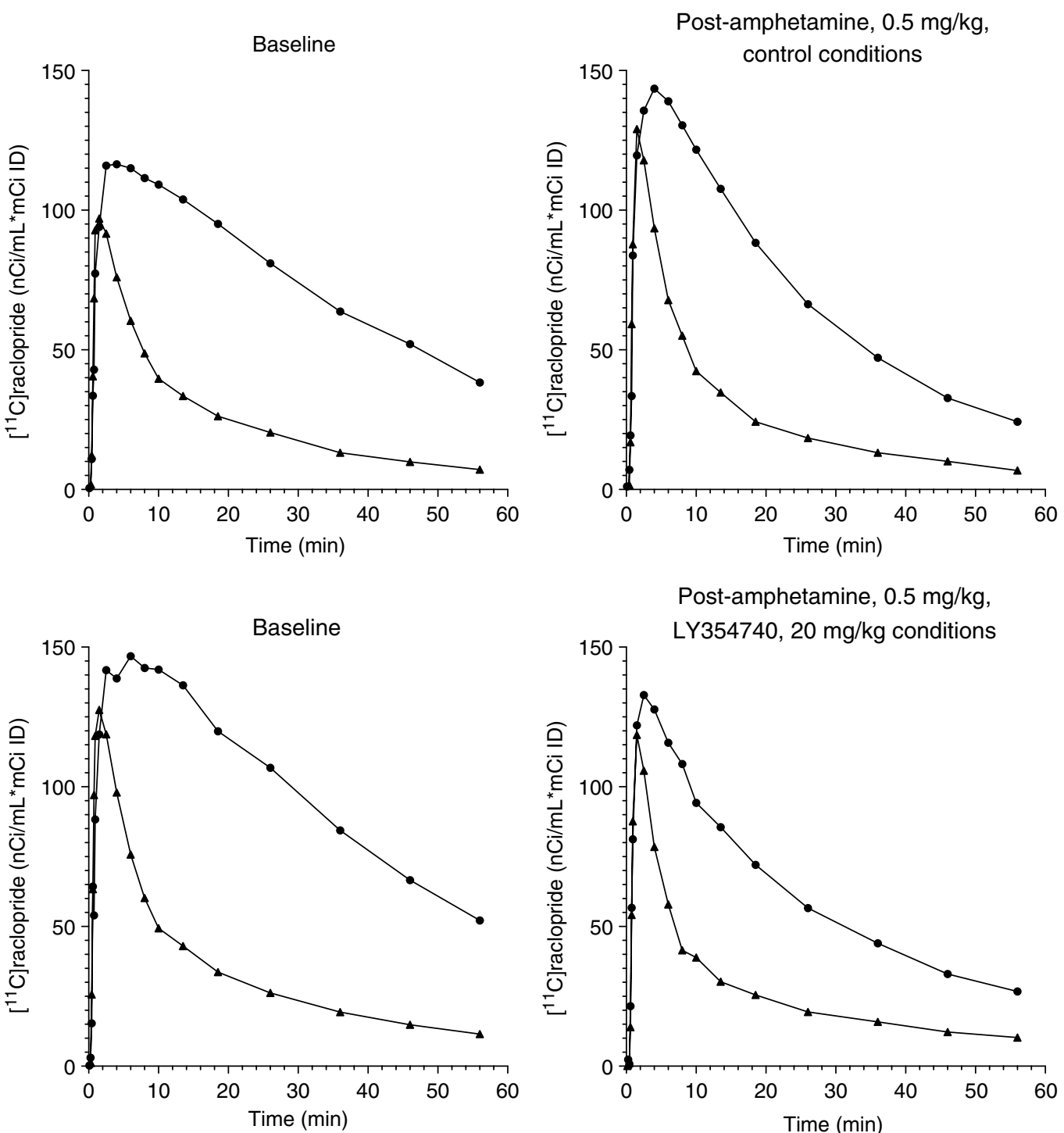

Post-amphetamine, $0.5 \mathrm{mg} / \mathrm{kg}$,

LY354740, $20 \mathrm{mg} / \mathrm{kg}$ conditions

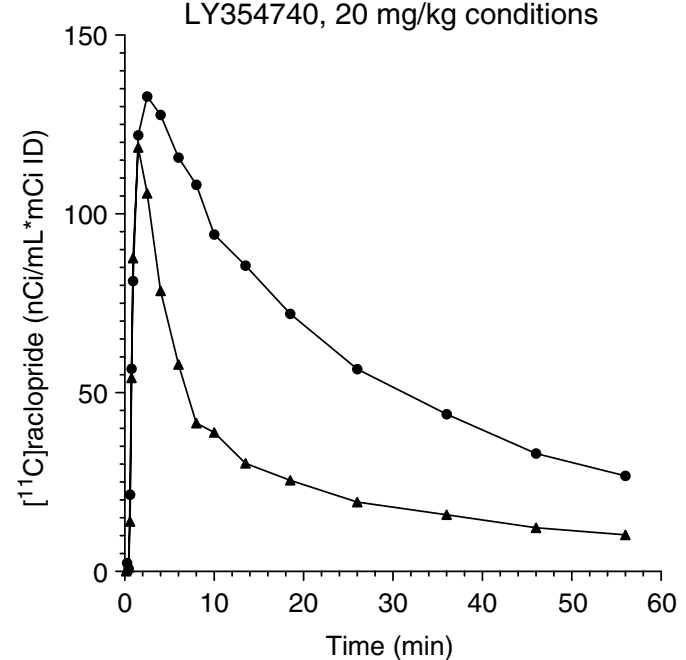

Figure I $\quad\left[{ }^{\prime \prime} \mathrm{C}\right]$ Raclopride time-activity curves, normalized by the injected doses $[\mathrm{nCi} /(\mathrm{ml} * \mathrm{mCi} \mathrm{ID})]$ in the cerebellum (triangles) and striatum (circles) measured in baboon A. Upper row (first experimental day): the baseline scan is shown on the left $\left(V_{3}{ }^{\prime \prime}=2.64\right)$, and the post-amphetamine $(0.5 \mathrm{mg} / \mathrm{kg})$ scan is shown on the right $\left(V_{3}^{\prime \prime}=1.88\right)$. Under these conditions, amphetamine induced a reduction of $29 \%$ in $\left[{ }^{\prime \prime} \mathrm{C}\right]$ raclopride $V_{3}{ }^{\prime \prime}$. Lower row (second experimental day): the baseline scan is shown on the left $\left(V_{3}{ }^{\prime \prime}=2.62\right)$, and the post-amphetamine $(0.5 \mathrm{mg} / \mathrm{kg})$ scan, obtained following pretreatment with LY354740 $(20 \mathrm{mg} / \mathrm{kg})$, is shown on the right $\left(V_{3}{ }^{\prime \prime}=1.64\right)$. Under these conditions, amphetamine induced a reduction of $37 \%$ in ${ }^{11} \mathrm{C}^{\prime}$ raclopride $V_{3}{ }^{\prime \prime}$. Thus, LY354740 pretreatment potentiated the effect of amphetamine on [ $\left.{ }^{\prime \prime} \mathrm{C}\right]$ raclopride $V_{3}{ }^{\prime \prime}$, from -29 to $-37 \%$.

ment with LY354740 $(20 \mathrm{mg} / \mathrm{kg})$, the amphetamine-induced reduction in $\left[{ }^{11} \mathrm{C}\right]$ raclopride $V_{3}^{\prime \prime}$ was significantly larger $(35 \pm 7 \%)$. This result suggests that stimulation of group II mGlu receptors increases amphetamine-induced DA release in non-human primates.

The quantification method used in this study (kinetic modeling using the arterial input function) is robust. Changes in regional blood flow and plasma CL potentially induced by the challenges do not affect the outcome measure $\left(V_{3}^{\prime \prime}\right)$, as the derivation method corrects for these effects. The measurement of the input function also allowed determination of the nonspecific binding distribution volume. The lack of effect of the challenges on the nonspecific binding indicated that the change in $V_{3}{ }^{\prime \prime}$ was exclusively due to change in receptors availability to $\left[{ }^{11} \mathrm{C}\right]$ raclopride binding. The data set also documented the excellent reproducibility of $\left[{ }^{11} \mathrm{C}\right]$ raclopride $V_{3}{ }^{\prime \prime}$ measurement with this method.

The decrease in $\left[{ }^{11} \mathrm{C}\right]$ raclopride and $\left[{ }^{123} \mathrm{I}\right] \mathrm{IBZM} \quad V_{3}{ }^{\prime \prime}$ following acute amphetamine challenge has been well validated as a measure of the change in $D_{2}$ receptor stimulation by DA due to amphetamine-induced DA release. First, manipulations that inhibit amphetamineinduced DA release, such as pretreatment with the DA synthesis inhibitor alpha-methyl-para-tyrosine or with the DA transporter blocker GR12909, inhibit the amphetamineinduced decrease in $\left[{ }^{123} \mathrm{I}\right] \mathrm{IBZM}$ or $\left[{ }^{11} \mathrm{C}\right]$ raclopride binding (Laruelle et al, 1997; Villemagne et al, 1999). The effect of methamphetamine on $\left[{ }^{11} \mathrm{C}\right]$ raclopride in vivo binding is also significantly blunted in patients with Parkinson's disease (Piccini et al, 2003). Second, combined microdialysis and imaging experiments in primates demonstrated 
that, under conditions of dopamine transporter (DAT) blockade, the magnitude of the decrease in ligand binding was correlated with the magnitude of the increase in

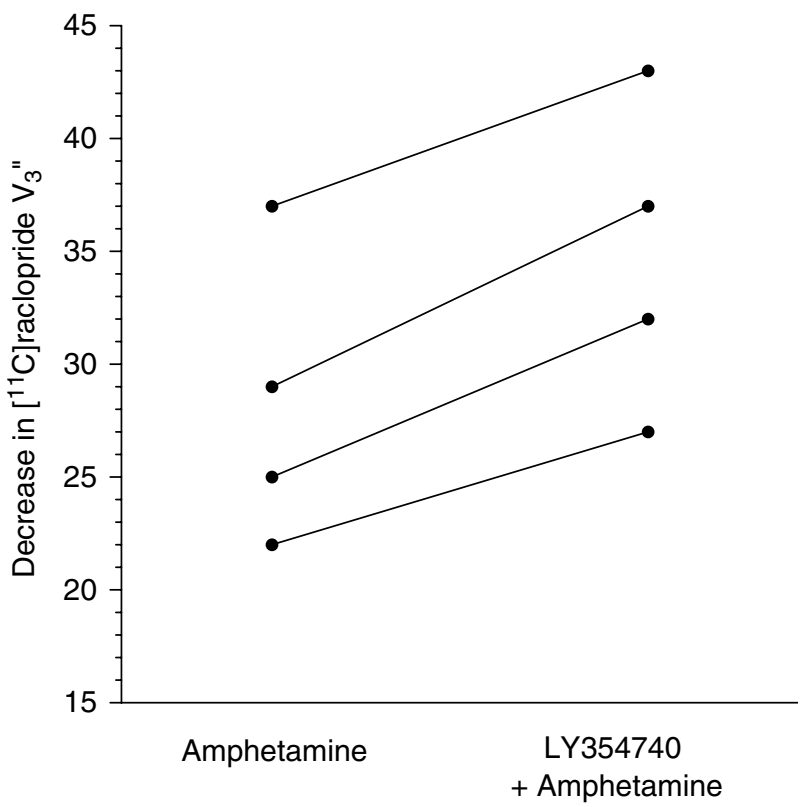

Figure 2 Amphetamine-induced decrease in $\left[{ }^{\prime \prime} C\right]$ raclopride $V_{3}$ " (expressed as percent decrease of baseline value) under control conditions (left) and following LY354740 pretreatment (right). The reduction in [ 'C]raclopride $V_{3}$ " was significantly larger under LY354740 pretreatment condition compared to control conditions (repeated measures ANOVA, $p=0.002)$. extracellular DA induced by the challenge (Breier et al, 1997; Laruelle et al, 1997; Tsukada et al, 1999a, b). Together, these data validate the use of $\left[{ }^{11} \mathrm{C}\right]$ raclopride $V_{3}^{\prime \prime}$ to monitor acute changes in DA synaptic activity.

The information provided by this noninvasive imaging technique is different from that provided by microdialysis. Administration of drugs (such as nicotine) that do increase DA cell firing and DA synaptic concentration without blocking the DAT are associated with reduced $\left[{ }^{11} \mathrm{C}\right]$ raclopride binding in the absence of detectable changes in extracellular DA measured with microdialysis (Kim et al, 1998; Tsukada et al, 1999a, b, 2000). The reason for this apparent discrepancy is that the DAT are effective at preventing the diffusion of synaptic DA to the extracellular space (Tsukada et al, 2000). Thus, $\left[{ }^{11} \mathrm{C}\right]$ raclopride imaging provides a more direct measure of $\mathrm{D}_{2}$ receptor stimulation by DA than microdialysis (see, for further discussion, Laruelle, 2000). In addition, this method is noninvasive,

Table 5 Modulation of Amphetamine-Induced $\Delta V_{3}{ }^{\prime \prime}$ by LY354740

\begin{tabular}{|c|c|c|c|}
\hline Condition & Baseline scan & Post-LY354740 scan & LY354740 effect \\
\hline Baboon & $V_{3}^{\prime \prime}$ & $V_{3}^{\prime \prime}$ & $\Delta V_{3}^{\prime \prime}(\%)$ \\
\hline D & 2.61 & 2.92 & 12 \\
\hline$D$ & 3.57 & 4.07 & 14 \\
\hline Mean $\pm S D$ & $3.09 \pm 0.67$ & $3.49 \pm 0.81$ & $13 \pm 2$ \\
\hline
\end{tabular}

Table 4 (a) Experimental Parameters during Amphetamine-Alone and Amphetamine/LY354740 Conditions and (b) Isoflurane Levels during Amphetamine Alone and Amphetamine/LY354740 Conditions

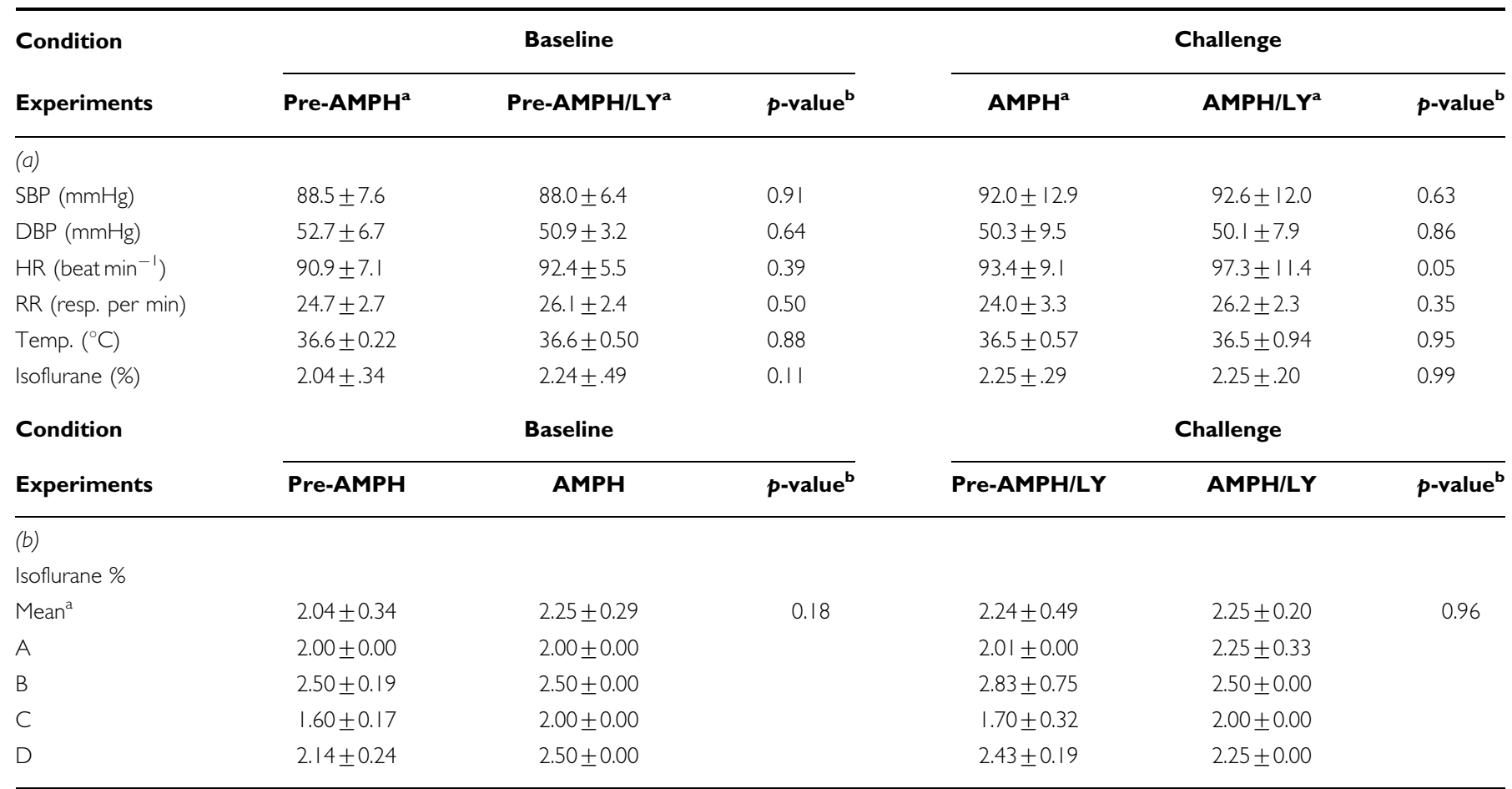

$\mathrm{SBP}=$ systolic blood pressure; $\mathrm{DBP}=$ diastolic blood pressure; $\mathrm{HR}=$ heart rate; $\mathrm{RR}=$ respiratory rate.

a Mean (of time averages for $n=4$ animals) $\pm S D$.

${ }^{\mathrm{b}}$ Repeated measures ANOVA, $\mathrm{df}=(1,3)$. 
and similar experiments can be conducted in animals and humans. It should however be pointed out that the duration of the effect of amphetamine on $\left[{ }^{11} \mathrm{C}\right]$ raclopride or ${ }^{123}$ I]IBZM $V_{3}$ " exceeds the duration of the increase in extracellular DA (Laruelle et al, 1997). This observation suggests that mechanisms other than simple binding competition, such as DA-induced receptor internalization, are involved in this response (see, for further discussion, Laruelle, 2000).

In this study, LY354740 enhanced the effect of amphetamine on $\left[{ }^{11} \mathrm{C}\right]$ raclopride binding. The larger amphetamine effect after pretreatment with LY354740 was not due to sensitization, because the order of the two test days was counterbalanced. It was not due to increase in bioavailability of amphetamine, since plasma amphetamine levels did not differ between conditions. Nor is it likely to be a simple additive effect, as LY354740 alone, tested in one baboon, did not cause a decrease of $\left[{ }^{11} \mathrm{C}\right]$ raclopride binding. The results of this study should be discussed in the context of the model of GLU-DA interaction introduced by Carlsson (Carlsson et al, 1999; Kegeles et al, 2000). According to this model, activity of midbrain DA neurons is modulated by cortical and limbic structures via both an activating pathway and an inhibitory pathway. The activating pathway is provided by a polysynaptic glutamatergic pathway onto the DA cells (see discussion and references in Gariano and Groves, 1988; Murase et al, 1993; Karreman and Moghaddam, 1996; Shim et al, 1996; see discussion and references in Carr and Sesack, 2000). The inhibitory pathway is provided by cortical glutamatergic efferents to midbrain GABAergic interneurons and striatomesencephalic GABA neurons (Carr and Sesack, 2000; Takahata and Moghaddam, 2000). According to this model, the net effect of reduced GLU transmission on striatal DA function under resting conditions is difficult to predict, since this intervention will affect both activating and inhibitory pathways. In contrast, this model predicts that impaired glutamatergic transmission will result in exaggerated DA release under conditions of DA activation (such as during stress or after amphetamine challenge).

Accordingly, under resting conditions, the effects of ketamine on $\left[{ }^{11} \mathrm{C}\right]$ raclopride have been inconsistent. While three studies reported that ketamine induced decrease in $\left[{ }^{11} \mathrm{C}\right]$ raclopride $V_{3}{ }^{\prime \prime}$ in humans (Breier et al, 1998; Smith et al, 1998; Vollenweider et al, 2000), three other studies (Kegeles et al, 2000, 2002; Aalto et al, 2002) did not detect any effect of ketamine on $\left[{ }^{123} \mathrm{I}\right] \mathrm{IBZM}$ or $\left[{ }^{11} \mathrm{C}\right]$ raclopride $V_{3}^{\prime \prime}$ in humans. These latter results are consistent with a microdialysis study that failed to detect any effect of PCP or ketamine on extracellular striatal DA levels in awake rhesus monkeys, even under condition of DAT blockade (Adams et al, 2002). In the current study, administration of LY354740 alone failed to significantly decrease $\left[{ }^{11} \mathrm{C}\right]$ raclopride $\Delta V_{3}^{\prime \prime}$ and instead an increase of $\Delta V_{3}^{\prime \prime}$ was noted. However, given the low number of studies (two studies in one baboon), this should be confirmed by inclusion of more subjects.

In contrast, systemic administration of noncompetitive NMDA antagonists increased amphetamine-induced DA release measured with microdialysis in rodents (Miller and Abercrombie, 1996) and with SPECT in humans (Kegeles et al, 2000). These observations were consistent with the
Carlsson model. Nonetheless, given the ambiguity of the noncompetitive NMDA antagonist effects on GLU transmission (see Introduction), it was important to further validate this model using a different strategy to blunt glutamatergicmediated responses. Here, we used mGlu2/3 agonism to blunt evoked GLU release. The increase in the amphetamine effect on $\left[{ }^{11} \mathrm{C}\right]$ raclopride $V_{3}$ " was enhanced following LY354740 administration. This observation was consistent with the hypothesis that LY354740 administration impaired the glutamatergic-mediated, negative feedback pathway, normally activated under these conditions. Therefore, the data of the present study further support the hypothesis that the exaggerated response of the DA system after amphetamine administration in schizophrenia might stem from hypofunctional glutamatergic transmission.

LY354740 is a highly selective group II mGLU receptor agonist, with nanomolar affinity for the mGlu2 $\left(K_{\mathrm{i}}=75\right.$ nmol/l) and mGlu3 $\left(K_{\mathrm{i}}=93 \mathrm{nmol} / \mathrm{l}\right)$ receptors (Schoepp et al, 1999). LY354740 has no activity on kainate, AMPA, or NMDA receptors, on group III metabotropic receptors mGlu4 and mGlu7 $\left(K_{\mathrm{i}}>100 \mu \mathrm{mol} / \mathrm{l}\right)$ or on group I metabotropic receptors (mGlu1 and mGlu5, $K_{\mathrm{i}}>300 \mu \mathrm{mol} / \mathrm{l}$ ) (Monn et al, 1997). In the low micromolar range, agonist responses at the group III mGlu receptors mGlu6 and mGlu8 have been reported (Monn et al, 1999). Yet, activation of group III mGlu receptors inhibits amphetamine-stimulated DA release (Mao et al, 2000; Mao and Wang, 2001). Therefore, it is unlikely that the effect of LY354740 observed in this experiment was mediated by mGlu6 and mGlu8 stimulation.

A full dose-response curve would be desirable to fully characterize the interaction between LY354740 and $\left[{ }^{11} \mathrm{C}\right]$ raclopride $\Delta V_{3}{ }^{\prime \prime}$. In one preliminary experiment, a lower dose of LY354740 $(10 \mathrm{mg} / \mathrm{kg})$ was tested in baboon B. This dose resulted in a $\left[{ }^{11} \mathrm{C}\right]$ raclopride $\Delta V_{3}{ }^{\prime \prime}$ of $-38 \%$, a value similar to the one observed under control condition $(-37 \%)$, and lower than observed following a larger dose of LY354740 $(20 \mathrm{mg} / \mathrm{kg},-43 \%)$. The effects of larger doses of LY354740 on this response remain to be tested, but are likely to be less informative, as activation of group III mGlu receptors might become involved.

It is known that isoflurane anesthesia increases the magnitude of $\left[{ }^{11} \mathrm{C}\right]$ raclopride $\Delta V_{3}{ }^{\prime \prime}$ following amphetamine and other pharmacological agents (Tsukada et al, 1999a, b, 2002). The same dose of isoflurane was used in both experiments and isoflurane administration was stable during the PET scans. Furthermore, no relationship was observed between the isoflurane dose required to maintain the animal under stable anesthesia and the amplification of $\left[{ }^{11} \mathrm{C}\right]$ raclopride $\Delta V_{3}{ }^{\prime \prime}$ elicited by LY354740. Similarly, no differences in vital signs were observed between amphetamine-alone and amphetamine plus LY354740 experiments, and this was true both before and after the challenge. Therefore, it is unlikely that isoflurane anesthesia alone caused the amplification of the amphetamine-induced DA release by LY354740, although an interaction between LY354740 and isoflurane cannot be excluded.

The pathophysiology of a hypofunctional glutamatergic transmission in schizophrenia is still unresolved. Interestingly, Tsai et al (1995) described increased levels of $\mathrm{N}$-acetylaspartylglutamate (NAAG) in schizophrenic brains. This observation is particularly relevant to the present 
study, as NAAG is an agonist at mGlu3 receptors (Wroblewska et al, 1997, 1998). Hypothetically, increased NAAG may lead to stimulation of mGlu3 receptors, decreased glutamate levels, and, as suggested here, dysregulation of the DA system.

In conclusion, this study demonstrated that acute activation of the mGlu2/3 receptors is associated with an increased amphetamine-induced DA release in baboons. This observation is consistent with the hypothesis that the increased amphetamine-induced DA release associated with schizophrenia may result from a deficiency in presynaptic glutamate control of DA neurotransmission, and further supports the development of pharmacological strategies aimed at enhancing glutamate function in schizophrenia.

\section{ACKNOWLEDGEMENTS}

We would like to thank Samir Abdelhadi, Mohammed Ali, Elizabeth Hackett, Kimchung Ngo, Van Phan, and Lyuzdmila Savenkova for excellent technical assistance. This work was supported by the National Alliance for Research in Schizophrenia and Depression (NARSAD), the Lieber Center for Schizophrenia Research at Columbia University, the Public Health Service (NIMH K02 MH01603, NIMH 1 K08 MH01594, NIMH MH59342-01), the Dutch Foundation for Scientific Research (NWO), Foundation 'de Drie Lichten', the Netherlands, and the Society for Nuclear Medicine (Cassen Fellowship), USA.

None of the authors have any involvement, financial or otherwise, that might potentially bias the work presented in this paper.

\section{REFERENCES}

Aalto S, Hirvonen J, Kajander J, Scheinin H, Nagren K, Vilkman H et al (2002). Ketamine does not decrease striatal dopamine D2 receptor binding in man. Psychopharmacology (Berlin) 164: 401.

Abi-Dargham A, Gil R, Krystal J, Baldwin R, Seibyl J, Bowers M et al (1998). Increased striatal dopamine transmission in schizophrenia: confirmation in a second cohort. Am J Psychiatry 155: 761-767.

Adams BW, Bradberry CW, Moghaddam B (2002). NMDA antagonist effects on striatal dopamine release: microdialysis studies in awake monkeys. Synapse 43: 12-18.

Battaglia G, Monn JA, Schoepp DD (1997). In vivo inhibition of veratridine-evoked release of striatal excitatory amino acids by the group II metabotropic glutamate receptor agonist LY354740 in rats. Neurosci Lett 229: 161.

Breier A, Adler CM, Weisenfeld N, Su TP, Elman I, Picken L et al (1998). Effects of NMDA antagonism on striatal dopamine release in healthy subjects: application of a novel PET approach. Synapse 29: 142-147.

Breier A, Su TP, Saunders R, Carson RE, Kolachana BS, deBartolomeis A et al (1997). Schizophrenia is associated with elevated amphetamine-induced synaptic dopamine concentrations: evidence from a novel positron emission tomography method. Proc Natl Acad Sci USA 94: 2569-2574.

Brix G, Zaers J, Adam LE, Bellemann ME, Ostertag H, Trojan H et al (1997). Performance evaluation of a whole-body PET scanner using the NEMA protocol. National Electrical Manufacturers Association. J Nucl Med 38: 1614-1623.

Carlsson A (1978). Antipsychotic drugs, neurotransmitters, and schizophrenia. Am J Psychiatry 135: 165-173.
Carlsson A, Waters N, Carlsson ML (1999). Neurotransmitter interactions in schizophrenia-therapeutic implications. Biol Psychiatry 46: 1388-1395.

Carr DB, Sesack SR (2000). Projections from the rat prefrontal cortex to the ventral tegmental area: target specificity in the synaptic associations with mesoaccumbens and mesocortical neurons. J Neurosci 20: 3864-3873.

Davis KL, Kahn RS, Ko G, Davidson M (1991). Dopamine in schizophrenia: a review and reconceptualization. Am J Psychiatry 148: 1474-1486.

Di Iorio P, Battaglia G, Ciccarelli R, Ballerini P, Giuliani P, Poli A et al (1996). Interaction between A1 adenosine and class II metabotropic glutamate receptors in the regulation of purine and glutamate release from rat hippocampal slices. J Neurochem 67: 302-309.

Duvaldestin P (1981). Pharmacokinetics in intravenous anaesthetic practice. Clin Pharmacokinet 6: 61-82.

East SJ, Hill MP, Brotchie JM (1995). Metabotropic glutamate receptor agonists inhibit endogenous glutamate release from rat striatal synaptosomes. Eur J Pharmacol 277: 117-121.

Gandelman MS, Baldwin RM, Zoghbi SS, Zea-Ponce Y, Innis RB (1994). Evaluation of ultrafiltration for the free-fraction determination of single photon emission computed tomography (SPECT) radiotracers: beta-CIT, IBF, and iomazenil. J Pharm Sci 83: 1014-1019.

Gariano RF, Groves PM (1988). Burst firing induced in midbrain dopamine neurons by stimulation of the medial prefrontal and anterior cingulate cortices. Brain Res 462: 194-198.

Hassoun W, Le Cavorsin M, Ginovart N, Zimmer L, Gualda V, Bonnefoi $\mathrm{F}$ et al (2003). PET study of the $\left[{ }^{11} \mathrm{C}\right]$ raclopride binding in the striatum of the awake cat: effects of anaesthetics and role of cerebral blood flow. Eur J Nucl Med Mol Imag 30: 141-148.

Helton DR, Tizzano JP, Monn JA, Schoepp DD, Kallman MJ (1998). Anxiolytic and side-effect profile of LY354740: a potent, highly selective, orally active agonist for group II metabotropic glutamate receptors. J Pharmacol Exp Ther 284: 651-660.

Javitt DC, Zukin SR (1991). Recent advances in the phencyclidine model of schizophrenia. Am J Psychiatry 148: 1301-1308.

Jentsch JD, Roth RH (1999). The neuropsychopharmacology of phencyclidine: from NMDA receptor hypofunction to the dopamine hypothesis of schizophrenia. Neuropsychopharmacology 20: 201-225.

Jewett DM (1992). A simple synthesis of $\left[{ }^{11} \mathrm{C}\right]$ methyl triflate. Int $J$ Radiat Appl Instrum (A) 43: 1383-1385.

Karreman M, Moghaddam B (1996). The prefrontal cortex regulates the basal release of dopamine in the limbic striatum: an effect mediated by ventral tegmental area. J Neurochem 66: 589-598.

Kegeles LS, Abi-Dargham A, Zea-Ponce Y, Rodenhiser-Hill J, Mann JJ, Van Heertum RL et al (2000). Modulation of amphetamine-induced striatal dopamine release by ketamine in humans: implications for schizophrenia. Biol Psychiatry 48: 627-640.

Kegeles LS, Martinez D, Kochan LD, Hwang DR, Huang Y, Mawlawi $\mathrm{O}$ et al (2002). NMDA antagonist effects on striatal dopamine release: positron emission tomography studies in humans. Synapse 43: 19.

Kim SE, Shin I, Oh SJ, Kim SH, Choe YS, Choi Y et al (1998). Nicotine-induced dopamine release evaluated with in vivo ${ }^{3} \mathrm{H}$ raclopride binding studies: comparison with in vivo dialysis data. J Nucl Med 39: 54P.

Konradi C, Heckers S (2003). Molecular aspects of glutamate dysregulation: implications for schizophrenia and its treatment. Pharmacol Ther 97: 153-179.

Laruelle M (2000). Imaging synaptic neurotransmission with in vivo binding competition techniques: a critical review. J Cereb Blood Flow Metab 20: 423-451. 
Laruelle M (2003). Dopamine transmission in the schizophrenic brain. In: Weinberger DR, Hirsch S (eds). Schizophrenia, 2nd edn. Blackwell Publishing: Oxford, UK. pp 365-387.

Laruelle M, Abi-Dargham A, Innis RB (1998). Imaging receptor occupancy by endogenous transmitters in humans. In: Carson R, Daube-Whiterspoon ME, Herscovith P (eds). Quantitative Functional Brain Imaging with Positron Emission Tomography. Academic Press: San Diego.

Laruelle M, Abi-Dargham A, van Dyck CH, Gil R, De Souza CD, Erdos J et al (1996). Single photon emission computerized tomography imaging of amphetamine-induced dopamine release in drug free schizophrenic subjects. Proc Natl Acad Sci USA 93: 9235-9240.

Laruelle M, Iyer RN, Al-Tikriti MS, Zea-Ponce Y, Malison R, Zoghbi SS et al (1997). Microdialysis and SPECT measurements of amphetamine-induced dopamine release in nonhuman primates. Synapse 25: 1-14.

Laruelle M, Wallace E, Seibyl JP, Baldwin RM, Zea-Ponce Y, Zoghbi SS et al (1994). Graphical, kinetic, and equilibrium analyses of in vivo $\left[{ }^{123} \mathrm{I}\right]$ beta-CIT binding to dopamine transporters in healthy human subjects. J Cereb Blood Flow Metab 14: 982-994.

Levenberg K (1944). A method for the solution of certain problems in least squares. Q Appl Math 2: 164-168.

Mao L, Lau YS, Wang JQ (2000). Activation of group III metabotropic glutamate receptors inhibits basal and amphetamine-stimulated dopamine release in rat dorsal striatum: an in vivo microdialysis study. Eur J Pharmacol 404: 289-297.

Mao L, Wang JQ (2001). Distinct inhibition of acute cocainestimulated motor activity following microinjection of a group III metabotropic glutamate receptor agonist into the dorsal striatum of rats. Pharmacol Biochem Behav 67: 93-101.

Miller DW, Abercrombie ED (1996). Effects of MK-801 on spontaneous and amphetamine-stimulated dopamine release in striatum measured with in vivo microdialysis in awake rats. Brain Res Bull 40: 57-62.

Mintun MA, Raichle ME, Kilbourn MR, Wooten GF, Welch MJ (1984). A quantitative model for the in vivo assessment of drug binding sites with positron emission tomography. Ann Neurol 15: 217-227.

Moghaddam B, Adams B, Verma A, Daly D (1997). Activation of glutamatergic neurotransmission by ketamine: a novel step in the pathway from NMDA receptor blockade to dopaminergic and cognitive disruptions associated with the prefrontal cortex. J Neurosci 17: 2921-2927.

Moghaddam B, Adams BW (1998). Reversal of phencyclidine effects by a group II metabotropic glutamate receptor agonist in rats. Science 281: 1349-1352.

Monn JA, Valli MJ, Massey SM, Hansen MM, Kress TJ, Wepsiec JP et al (1999). Synthesis, pharmacological characterization, and molecular modeling of heterobicyclic amino acids related to $(+)-$ 2-aminobicyclo[3.1.0] hexane-2,6-dicarboxylic acid (LY354740): identification of two new potent, selective, and systemically active agonists for group II metabotropic glutamate receptors. J Med Chem 42: 1027-1040.

Monn JA, Valli MJ, Massey SM, Wright RA, Salhoff CR, Johnson BG et al (1997). Design, synthesis, and pharmacological characterization of (+)-2-aminobicyclo[3.1.0]hexane-2,6-dicarboxylic acid (LY354740): a potent, selective, and orally active group 2 metabotropic glutamate receptor agonist possessing anticonvulsant and anxiolytic properties. J Med Chem 40: 528-537.

Murase S, Grenhoff J, Chouvet G, Gonon FG, Svensson TH (1993). Prefrontal cortex regulates burst firing and transmitter release in rat mesolimbic dopamine neurons studied in vivo. Neurosci Lett 157: $53-56$.

Nakanishi S, Masu M (1994). Molecular diversity and functions of glutamate receptors. Annu Rev Biophys Biomol Struct 23 319-348.
Olney JW, Farber NB (1995). Glutamate receptor dysfunction and schizophrenia. Arch Gen Psychiatry 52: 998-1007.

Piccini P, Pavese N, Brooks DJ (2003). Endogenous dopamine release after pharmacological challenges in Parkinson's disease. Ann Neurol 53: 647-653.

Pin JP, De Colle C, Bessis AS, Acher F (1999). New perspectives for the development of selective metabotropic glutamate receptor ligands. Eur J Pharmacol 375: 277-294.

Reimer ML, Mamer OA, Zavitsanos AP, Siddiqui AW, Dadgar D (1993). Determination of amphetamine, methamphetamine and desmethyldeprenyl in human plasma by gas chromatography/ negative ion chemical ionization mass spectrometry. Biol Mass Spectrom 22: 235-242.

Schoepp DD (2002). Metabotropic glutamate receptors. Pharmacol Biochem Behav 73: 285-286.

Schoepp DD, Jane DE, Monn JA (1999). Pharmacological agents acting at subtypes of metabotropic glutamate receptors. Neuropharmacology 38: 1431-1476.

Schoepp DD, Johnson BG, Wright RA, Salhoff CR, Mayne NG, Wu $S$ et al (1997). LY354740 is a potent and highly selective group II metabotropic glutamate receptor agonist in cells expressing human glutamate receptors. Neuropharmacology 36: 1-11.

Seeman P (1987). Dopamine receptors and the dopamine hypothesis of schizophrenia. Synapse 1: 133-152.

Shim SS, Bunney BS, Shi WX (1996). Effects of lesions in the medial prefrontal cortex on the activity of midbrain dopamine neurons. Neuropsychopharmacology 15: 437-441.

Smith GS, Schloesser R, Brodie JD, Dewey SL, Logan J, Vitkun SA et al (1998). Glutamate modulation of dopamine measured in vivo with positron emission tomography (PET) and ${ }^{11} \mathrm{C}$ raclopride in normal human subjects. Neuropsychopharmacology 18: $18-25$.

Takahata R, Moghaddam B (2000). Target-specific glutamatergic regulation of dopamine neurons in the ventral tegmental area. J Neurochem 75: 1775-1778.

Tsai GC, Passani LA, Slusher BS, Carter R, Baer L, Kleinman JE et al (1995). Abnormal excitatory neurotransmitter metabolism in schizophrenic brains. Arch Gen Psychiatry 52: 829-836.

Tsukada H, Harada N, Nishiyama S, Ohba H, Kakiuchi T (2000). Cholinergic neuronal modulation alters dopamine D2 receptor availability in vivo by regulating receptor affinity induced by facilitated synaptic dopamine turnover: positron emission tomography studies with microdialysis in the conscious monkey brain. J Neurosci 20: 7067-7073.

Tsukada H, Miyasato K, Kakiuchi T, Nishiyama S, Harada N, Domino EF (2002). Comparative effects of methamphetamine and nicotine on the striatal $[(11) \mathrm{C}]$ raclopride binding in unanesthetized monkeys. Synapse 45: 207-212.

Tsukada H, Nishiyama S, Kakiuchi T, Ohba H, Sato K, Harada N (1999a). Is synaptic dopamine concentration the exclusive factor which alters the in vivo binding of $\left[{ }^{11} \mathrm{C}\right]$ raclopride? PET studies combined with microdialysis in conscious monkeys. Brain Res 841: 160-169.

Tsukada H, Nishiyama S, Kakiuchi T, Ohba H, Sato K, Harada N et al (1999b). Isoflurane anesthesia enhances the inhibitory effects of cocaine and GBR12909 on dopamine transporter: PET studies in combination with microdialysis in the monkey brain. Brain Res 849: 85-96.

van Berckel BNM (2003). Glutamate and schizophrenia. Curr Neuropharmacol 1: 351-370.

Villemagne VL, Wong DF, Yokoi F, Stephane M, Rice KC, Matecka D et al (1999). GBR12909 attenuates amphetamine-induced striatal dopamine release as measured by [(11)C]raclopride continuous infusion PET scans. Synapse 33: 268-273.

Vollenweider FX, Vontobel P, Oye I, Hell D, Leenders KL (2000). Effects of $(S)$-ketamine on striatal dopamine: a $\left.{ }^{11} \mathrm{C}\right]$ raclopride PET study of a model psychosis in humans. J Psychiatr Res 34: 35-43. 
Weinberger DR (1987). Implications of the normal brain development for the pathogenesis of schizophrenia. Arch Gen Psychiatry 44: 660-669.

Woods RP, Cherry SR, Mazziotta JC (1992). Rapid automated algorithm for aligning and reslicing PET images. J Comput Assist Tomogr 16: 620-633.
Wroblewska B, Santi MR, Neale JH (1998). N-acetylaspartylglutamate activates cyclic AMP-coupled metabotropic glutamate receptors in cerebellar astrocytes. Glia 24: 172-179.

Wroblewska B, Wroblewski JT, Pshenichkin S, Surin A, Sullivan SE, Neale JH (1997). $N$-acetylaspartylglutamate selectively activates mGluR3 receptors in transfected cells. J Neurochem 69: 174-181. 